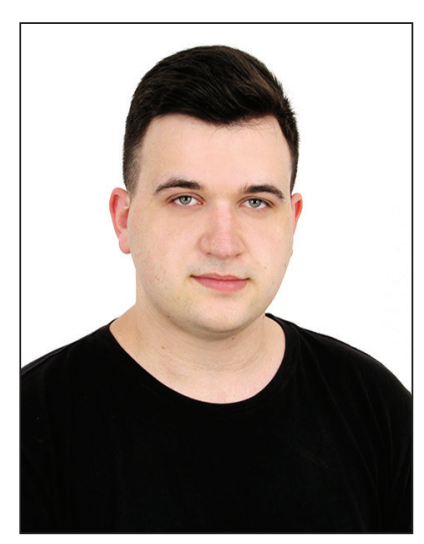

\author{
Maidanik Serhii Viktorovich, \\ Postgraduate Student of the European Union \\ Law Department, Yaroslav Mudryi National \\ Law University, Ukraine, Kharkiv \\ e-mail: s.v.maydanik@nlu.edu.ua \\ ORCID 0000-0001-7837-5265
}

\title{
EUROPEAN UNION DISABILITY POLICY: SUPRANATIONAL LEVEL OF LEGAL REGULATION
}

In the modern European Union, disability policy (which was paid extremely little attention in the framework of traditional social policy in the late twentieth century) became one of the priorities of legal regulation. Today, this area of social policy includes not only social protection and integration in the labor market, but also takes care of the problem of ensuring equal rights and non-discrimination. In the context of this evolution, the article examines these questions: what is the legal nature of the European Union? What impact does the emergence of a supranational level of legal regulation have on disability policy? How does the international law and European legal regulation in the field of disability relate? How has the terminology changed in the regulations of the international, regional and national levels? How has EU disability policy evolved and what factors influenced on it? The article presents the results of a systematic analysis of EU regulations on disability policy, covering the period from 1951 to 2020.

Keywords: persons with disabilities; disability rights; Equal Rights; social model; European Union; Social Policy; competence; Convention on the Rights of Persons with Disabilities

Майданік C. В., аспірант кафедри права Європейського Союзу, Національний юридичний університет імені Ярослава Мудрого, Україна, м. Харків.

e-mail: s.v.maydanik@nlu.edu.ua ; ORCID 0000-0001-7837-5265

Політика Європейського Союзу у сфері інвалідності: наднаціональний рівень правового регулювання

У сучасному Європейському Союзі політика в сфері інвалідності, якій наприкіниі XX ст. приділялося надзвичайно мало уваги в рамках традииійної сочіальної політики, стала одним із пріоритетів правового регулювання. Сьогодні цей напрям сочіальної політики включає не тільки соціальний захист та інтеграцію на ринку пращі, але й опікується проблемою забезпечення рівності прав та недискримінацію. У контексті такої еволюиї у статті досліджуються питання правової природи впливу Свропейського Союзу на політику інвалідності появи наднаціонального рівня правового регулювання, співвідношення міжнародно-правового i загальноєвропейського рівня правового регулювання у сфері інвалідності, зміни термінологї нормативно-правових актів міжнародно-правового, регіонального і національного рівнів, еволющіонування факторів політики ЄС щодо інвалідності. У статті представлено результати 
системного аналізу нормативних документів СС щодо політики у сфері інвалідності, які охоплюють період з 1951 по 2020 рік.

Ключові слова: особи з інвалідністю; права осіб з інвалідністю; рівні права; соціальна модель; Європейський Союз; соціальна політика; компетенція; Конвенція про права осіб з інвалідністю.

Problem setting. European integration is one of the most significant features of the second half of the XX century. The European Union embodies a new stage in the development of mankind: the creation of a new type of international organization, in the legal nature of which there is a powerful supranational component. Integration structures based on international treaties (reflecting a common system of values and focus on common interests, guarantying the rule of law and equality of all member states) were able to unite states to achieve political goals (peace, security and prosperity in Europe, the establishment of the principles of democracy and the rule of law, the formation of a European identity, etc.) through effective economic cooperation for the first time in the history of the continent. However, since European integration was and remains primarily an economic project, there has long been a selective Europeanization of the basic functions of the state. As a result, human rights protection and social policy have long been on the periphery of EU policy. Recognizing the lack of democracy and the fact that EU social policy should be one of the key instruments of integration, as the success of the Single Internal Market depends on the social dimension [81], has changed the situation: the European Union is gradually taking care of human and citizen rights. This is evidenced by the introduction of the European social model, the adoption of the Community Charter of the Fundamental Social Rights of Workers (1989) and the Charter of Fundamental Rights of the European Union (2000). However, the general trend towards EU democratization does not mean that this process has equally affected all categories of people: for instance, people with disabilities, who are a significant part of all societies around the world, face many social barriers which are severely limiting their rights and freedoms and hinder their lives' quality improvement. This necessitates a scientific justification for the relevant changes in the European Union's policy towards this category of persons.

Analysis of recent research and publications. Scholars' attention to the issue of people with disabilities has been permanently growing since the 1970s. However, scientific works devoted to the legal regulation of this category of persons lives are still an absolute minority. Most of them are devoted to the evolution of the legal status of persons with disabilities, their legal capacity, analysis of the problems of their individual rights ensuring (especially the right to education and work), content analysis of the Convention on the Rights of Persons with Disabilities and experience in determining the legal status of persons with disabilities in individual countries [3]. At the same time, there is a shortage of legal researches on disability issues both at the EU level [24] and among domestic researchers [59; 64; 65]. Analysis of scientific publications shows that, despite the growing number of extremely interesting works, the degree of study of the problem of legal regulation of the rights of persons with 
disabilities in the EU by both foreign and domestic authors could not be considered sufficient and it requires further research.

Statement of the article objective. The purpose of the scientific article is a scientific-theoretical study of the principles of legal regulation of the rights and freedoms of persons with disabilities provision in the European Union, revealing its ratio with international and national legal approaches of member states to this problem.

Presentation of the main body of the article. The attitude of the state and society towards people with disabilities has been extremely negative for most of history. Our distant ancestors believed in the demonic nature of diseases and pathologies, which was widely reflected in the folklore and traditions of many peoples. Eugenistic ideas were practiced long before the emergence of the relevant scientific terms. The concept of the ideal citizen prevailed in ancient times. Accordingly, children who did not conform to the patterns of biological normalcy from childhood, which allowed a person to effectively perform his/her social function, were forcibly deprived of life. In this case, infanticide was justified by both religious and legal considerations (for example, Table IV of the Law of the Twelve Tables provided for the murder of children, who are characterized by exceptional ugliness [60]).

In the Middle Ages, people with disabilities continued to suffer from the curse of the deities. Such people were left at best in church hospices, they were doomed to beg, to be clowns.

In the late XIX - early XX centuries in North America and Europe, the idea of a eugenic state policy that included forced sterilization and deprivation of life of people with disabilities ("social losers"), which was implemented by some states in the United States ${ }^{1}$ and Germany ${ }^{2}$, became widespread. Unfortunately, it should be noted that the problem of forced sterilization of women with disabilities in Europe still remains unresolved ${ }^{3}$.

\footnotetext{
${ }^{1}$ In 1926, 23 states had involuntary sterilization laws motivated primarily by eugenic ideas. A legislative ban on the sterilization of "social losers" began in 1907 in Indiana [49; 58].

${ }^{2}$ In Germany, forced sterilization began in the Weimar Republic under a law that encouraged the sterilization of "unfit" patients. On July 14, 1933, the «Law for the Prevention of Genetically Diseased Offspring» required the compulsory sterilization of people with any of the diseases listed in the law. Decisions regarding sterilization were then made by «Hereditary Health Courts», which consisted of a 3-person panel. Two panel members were physicians. 360,000-375,000 people were forcibly sterilized in 1933-1939 [50; 62; 51].

${ }^{3}$ The EU Charter of Fundamental Rights provides for the prohibition of eugenic Practices (Article 3). The UN Convention on the Rights of Persons with Disabilities (CRPD) underlines everyone's right to make decisions for themselves, rather than have them made by anyone else. In 2015, the Committee on the Rights of Persons with Disabilities prepared Concluding observations on the initial report of the European Union. In this observations, the Committee expressed concern that persons with disabilities are exposed to involuntary treatment, including forced sterilization and abortion, in the European Union member States (para. 46) [13]. In July 2017, a high-level publication by the Office of the United Nations (UN) High Commissioner for Human Rights urged UN member states to repeal all legislation that allows forced sterilisation, forced abortion, and forced contraception to be carried out [48].
} 
The situation began to change after the Second World War with the establishment of the principles of a democratic, social, legal state as key principles of the constitutional order in Western Europe. The medical model of disability is being implemented. Due to the dependence of this category of people on the will of family, doctors and society, who didn't fully take into account their interests or did not take them into account at all, the possibility of their integration into public life was virtually ruled out [53].

The awareness that people with disabilities can be beneficial to society, but that they need rehabilitation measures, in which the state must be involved, was gradual. The problem of disability is a political problem and therefore requires social action and collective responsibility. Society and the state must take certain steps to ensure the participation of persons with disabilities in all spheres of life of society (social model). In this regard, the recognition by the World Health Organization (WHO) of the fact that disability is not an attribute of the individual, but a complex set of conditions, a lot of which are created by the social environment, is of a high importance [8, p. 22].

Persons with disabilities have the right to full social integration, but they are not given the opportunity. The prejudice and victimization were among the most important factors in their persistent exclusion from society and labor markets. That is why tacking invisibility of people with disabilities in society was a priority for civil society institutions of the European Communities/European Union.

Mark Priestley notes that in the late XX - early XXI centuries there was a situation when the most significant policy catalysts in the field of legal regulation of persons with disabilities were at the global level while the most significant implementation constraints were at the national level [72, p. 61].

Since the 1970s, international and European movements of persons with disabilities have initiated political discussions ${ }^{1}$ at the global and regional levels, which have eventually led to a gradual change in perceptions of persons with disabilities, their rights, full participation and the removal of structural barriers to inclusion [72]. It is still from the 1970s that the concept of human rights for persons with disabilities is embodied in two international documents: Declaration on the Rights of Mentally Retarded Persons [26] and Declaration on the Rights of Disabled Persons (1975) [25].

Unlike the Council of Europe, which adopted the Council of Europe's Convention on the Prevention and Combating of Violence against Women and Domestic Violence, European Union law does not contain rules aimed at protecting women with disabilities from forced sterilization [41].

${ }^{1}$ In particular, the question was discussed, should people with disabilities be considered as subjects and not as objects? An analysis of the issue in "Human Rights and Disability" prepared by a group of experts for the UN states that the disability rights debate is not so much about the enjoyment of specific rights as it is about ensuring the equal effective enjoyment of all human rights, without discrimination, by people with disabilities. The non-discrimination principle helps make human rights in general relevant in the specific context of disability, just as it does in the contexts of age, gender and children [55]. 
The awareness that disability and mental illness are two separate policy areas ("two policies and two philosophies") has been quite difficult at both the national and international levels [54; 34]. Today, the term "mentally retarded", which was used in the 1971 Declaration, is not used because it does not correspond to the modern understanding of disability.

Joanna Nowak-Michalska and a number of other authors point out that it is still with regard to the category of persons with disabilities, the legal regulation of ensuring their rights and freedoms at both the international and national levels is constantly faced with a terminological problem. People with disabilities are always more sensitive to the rules of legal technique that apply to them. Some terms, which is used in legal acts, are perceived by them as offensive or stigmatizing are rejected in favor of more neutral and inclusive ones. But over time, such new terms cease to serve their purpose (for example, due to the abandonment of the medical model of perception of people with disabilities in favor of social model), resulting in the need to find new words (objective and neutral) for defining this phenomenon [67; 5, p. 460; 22, p. 53]. Thus, in Eastern Europe, in particular in Ukraine and Poland, during the XVI - first half of XX century the term "каліка" was used in regulations (from the Turkish "kalık" - defective) [37; 27]. In other European countries, you could find other variations (for example, "abnormal"). In the XX century the term "cripple", because it had an obviously negative and offensive connotation was replaced by "persons with incomplete ability to work" (but the use of the adjective "incomplete" caused a negative reaction) or "abnormal" or "subnormal", and later by "disabled person". Beginning from the 1990s, the noun "disabled" (according to the medical model, was interpreted as weak, feeble, defective, with developmental disabilities ${ }^{1}$ ) was gradually replaced by the postmodified noun "disabled persons" or "persons with disabilities"2. It is obvious that the evolution of terminology was conditioned by socio-political changes, first of all by the intensification of social movements for the rights of persons with disabilities and the change of perceptions of such persons.

In 1976, the UN General Assembly, recognizing the need to promote the socialization of people with disabilities, proclaimed the 1981 International Year of Disabled Persons and called for an action plan development at the national, regional and international levels, with an emphasis on equalization of opportunities, rehabilitation and prevention of disabilities. An outcome of the International Year of Disabled Persons was the formulation of the World Program of Action concerning Disabled Persons adopted by the UN General Assembly (1982). To implement the tasks of the World Program the General Assembly proclaimed 1983-1992 the United Nations Decade of Disabled Persons. The main result of the Decade of Disabled Persons was the adoption of the Standard Rules on the

\footnotetext{
${ }^{1}$ In V.I. Dahl encyclopedic dictionary, the term "invalid" (from French) was interpreted as a person who did one's military service, an honored soldier, incapable of further service due to injury, old age [23].

${ }^{2}$ For example, it is biased to refer to someone as «blind»; one must say instead, «a person who is blind», «a person who uses a wheelchair» instead of «wheelchair bound» [82, p. 103, 251; 5].
} 
Equalization of Opportunities for Persons with Disabilities by the General Assembly on 20 December 1993 (resolution 48/96 annex) [78]. The Rules serve as a guidance for policy-making, taking action to remove obstacles and creating equal opportunity for persons with disabilities in society and development.

It is difficult to deny the fact that the process of ensuring that people with disabilities enjoy their human rights is slow and uneven. Non-discrimination, and the equal effective enjoyment of all human rights by people with disabilities, are therefore the dominant theme of the long-overdue reform in the way disability and the disabled are viewed throughout the world [55, P.1]. The Vienna Declaration and Programme of Action, adopted by the World Conference on Human Rights (1993) were of a high significance for persons' with disabilities rights provision at international law level. It emphasized that all human rights and fundamental freedoms are universal and thus unreservedly include persons with disabilities. Any direct discrimination or other negative discriminatory treatment of a disabled person is therefore a violation of his or her rights [87].

A turning point in the approach to disability was the adoption of the UN Convention on the Rights of Persons with Disabilities [57] and its Optional Protocol [85] on 13 December 2006, which entered into force in 2008. The Convention directly refers to the values promoted by the social model of disability, and uses the term "person with a disability". It is stated that disability is not a defining characteristic in determining a person's personality, but is only one of the many features that characterize it.

Adopted in the late XX - early XXI century decisions and documents show that the international community encouraged national and international protection of the rights of persons with disabilities.

Formation of legal regulation of persons with disabilities status in the EU. Coverage of the problem of human rights in the EU in most scientific sources devoted to European integration is characterized by a certain incompleteness and somewhat distorted ideas about the evolution of legal regulation in this sphere, as it was indicated by Groinne de Bъrca. Most authors ignore the brief but intense period in 1951-1954 (work on the draft European Political Community Treaty) when the question of human rights protection was prominent on the agenda of the European integration process and deliberately fail to explain the disappearance from the agenda of the new European Communities in 1957 [4]. The purpose of this article is not to cover the causes of this situation. However, it should be noted that at the initial stage of work on the draft European Political Community Treaty protection of fundamental freedoms within the new Community was to be one of its central aims [36;9]. At the same time only the Member States and not the Community institutions were to be specifically placed under an obligation to respect human rights, as the role of the Community was envisaged as a kind of strong-arm back-stop in the event of a serious failure on the part of a member state in protecting human rights and fundamental freedoms. The vision of human rights issues in the final draft of the European Political Community Treaty was somewhat different [4;60]: 
- protection of human rights within the Member States was explicitly declared to be one of the aims of the Community (Article 2 of the EPC Treaty);

- Community was given the power to make proposals to further the aims Article 2 (Article 55 EPC);

- guaranteeing the protection of human rights and fundamental freedoms provided for in Article 3 has been recognized as one of the criteria for acquisition for the Member States of the Council of Europe and for any other European State (Article 116 of the draft EPC Treaty);

- Community could conclude association agreements «with such third States as guarantee the protection of human rights and fundamental freedoms mentioned in Article 3».

The failure to ratify the Treaty on the European Defense Community resulted in the suspension of work on the draft European Political Community Treaty.

The project of European political integration in the field of human rights, which has been implemented since the entry into force of the Treaty on European Union (1992), is less ambitious ${ }^{1}$. It is connected with the desire of Member States to minimize their human rights obligations. It should therefore be acknowledged that if the draft European Political Community Treaty had entered into force in the 1950s, EU policy on human rights, and in particular the rights of persons with disabilities, would have been developed at a different pace and would have had a different content.

Human rights were not considered as a key element of the EU constitutional framework for a long time. Gráinne de Búrca considers that the silence of the founding Treaties on the subject is explained on the basis that human rights concerns were unrelated to the project of economic integration [4, p.649].

It should be noted that for a long time the founding Treaties contained no explicit reference to disability, and therefore no disability-specific competence existed [89]. That is, in fact, it was about the "invisibility of disabled people" within the EU treaty system. Legal regulation of a range of issues related to the rights of persons with disabilities was the responsibility of national governments ${ }^{2}$. Mentions of the rights of persons with disabilities, as well as the relevant responsibilities of the state are contained in the constitutions of Greece (Article 21, paragraph 2), Spain (Article

\footnotetext{
${ }^{1}$ In 1974-1996, the European Communities / European Union implemented four multi-year programs, which were mainly focused on the information exchange and best practices: 1) the initial action program for the vocational rehabilitation of persons with disabilities (1974-1979); 2) the first program of action on social integration of people with disabilities (1983-1988); 3) EMP-HELIOS 1 - Second Community action programme (EEC) for disabled people (HELIOS) (1988-1991); 4) EMP-HELIOS 2 - Third Community action programme (EEC) for disabled people (HELIOS II (1993-1996) [20; 21; 39; 40].

${ }^{2}$ Council Recommendation 86/379 / EEC (1986) became the first soft law instrument to deal directly with disability issues. It recommended to Member States «to take all appropriate measures to promote fair opportunities for disabled people in the field of employment and vocational training, including initial training and employment as well as rehabilitation and resettlement» and «to intensify and re-examine their policies to help disabled people, where appropriate after consulting disabled people's organizations and both sides of industry» [18].
} 
49), Italy (Article $38 \S \S 1$ and 3), Portugal (Article 71) and France (preamble). However, governments have been reluctant to implement the European Community's recommendations for concrete changes in disability policy. The development of a unified European approach to this issue is complicated by the existence of different models of the welfare state, some of which adhered to the paternalistic model of social protection, according to which people with disabilities are perceived as "objects" of charity, drug treatment and social protection. Such models are based on the paradigm of inability of a person to control himself, which accordingly requires the constant help of a third person, which determines the direction of his life [53, p.1041]. This paradigm does not correspond to the general principles of European integration, and therefore causes additional difficulties. The Amsterdam Treaty has played an important role in the legal regulation of issues related with guaranteeing the rights of persons with disabilities. First of all, it contained a general article on non-discrimination (Article 13), which also covered persons with disabilities [52]. Thus, the existence of the problem of discrimination on the grounds of disability was directly acknowledged. The Declaration concerning persons with a disability was also added to the Treaty, from the text of which it followed that the Community institutions must take into account the needs of persons with a disability when adopting measures under the former Art. 95 EC to approximate Member States' legislation.

However, since Art. 13 was of a programmatic nature (requiring the Community to take further steps to take the necessary measures to combat discrimination against persons with disabilities), it did not give rights directly to stakeholders and therefore its positive effect was limited. In order to implement measures aimed at ensuring the rights of persons with disabilities by the European Community, a number of procedural barriers had to be overcome, namely: the question on adoption of a certain measure or even a legislative act had to be initiated by the European Commission; later the EU Council should have consultation with the EU Parliament and make a decision unanimously ${ }^{1}$. On the basis of Art. 13 was adopted by Council Directive 2000/78/EC (establishing a general framework for equal treatment in employment and occupation). This Directive implements the principle of equal treatment in the area of employment and prohibits discrimination on various grounds, including disability [17]. In addition, a number of directives and regulations were adopted in the early 2000s [29; 30; 31; 32; 33; 75; 76], which affected the rights of persons with disabilities, as well as optional acts, including the Council Resolution on promoting the employment and social integration of persons with disabilities (2003) [19].

Despite the fact that persons with disabilities remain dissatisfied with the approach to solving the problem of discrimination against themselves comparing to the norms of the TEU, which deal with combating discrimination on the grounds of

\footnotetext{
${ }^{1}$ It was a rather difficult task, as despite the traditional support by the European Parliament for human rights issues, the final decision was taken by the Council. There was a lack of consensus among Member States on the need for mandatory Community action to combat discrimination against persons with disabilities at the end of the XX century.
} 
nationality or gender (the latter norms had direct effect), progress was made in the late XX and early XXI centuries on the issue of legal regulation by Member States to ensure the rights of persons with disabilities was obvious [91, p. 15].

The debate over disability models, which began in the EU in the 1970s, was important for adjusting EU policy. Some authors have noted that within the medical model, disability, like racism or sexism, is discrimination and social oppression. Once social barriers to the reintegration of people with physical impairments are removed, the disability itself is eliminated. While its supporters, on the contrary, believe that the Social Model of Disability down-play the role of biological and mental conditions in the lives of disabled people [2, p. 441-443]. In the end, the supporters of the Social Model of Disability won, whose approach to disability is reflected today in international legal acts, as well as in EU documents.

The Community Charter of Fundamental Social Rights for Workers (1989) contained a provision according to which:

- Any discrimination based on any ground such as... disability... shall be prohibited (Article 21);

- All disabled persons, whatever the origin and nature of their disablement, must be entitled to additional concrete measures aimed at improving their social and professional integration. These measures must concern, in particular, according to the capacities of the beneficiaries, vocational training, ergonomics, accessibility, mobility, means of transport and housing (Article 26) [83].

However, the Charter protected the rights of persons with disabilities only as employees and the protection of violated rights in court remained open [35, p. 664-665].

The Charter of Fundamental Rights of the European Union (2000) provided that "The Union recognizes and respects the right of persons with disabilities to benefit from measures designed to ensure their independence, social and occupational integration and participation in the life of the community" (Article 26) [7]. However, before the Lisbon Treaty, when it acquired the same legal force as the Founding Treaties, it was of a political nature. Accordingly, socio-economic rights were seen as ideological and political, not legal. The Charter provided for neither the establishment of new powers or tasks, nor their change, either for the Member States or for the Community/Union. As a result, each Member State had to decide independently on the legal exercise of the rights enshrined in the Charter [ 45 , p. 29-30, 92-93, 95]. Only after the entry into force by the Lisbon Treaty all EU institutions and bodies should respect the rights enshrined in the Charter when drafting EU law and policy, and the Member States while implementing Union legislation.

The most important legal development in 2000 was the adoption of the Council Directive 2000/78/EC of 27 November 2000 establishing a general framework for equal treatment in employment and occupation, which prohibits discrimination in employment on the grounds of disability and requires the provision of reasonable accommodation for people with disabilities [17]. 
The EU acceded to the UN Convention on the Rights of Persons with Disabilities (hereinafter - UN CRPD) in December 2010 [16] (the Union's preparation for the ratification of the CRPD took place within the framework of "Equal opportunities for people with disabilities: A European Action Plan"). For the EU, the UN CRPD entered into force on January 22, 2011'. But some elements of the UN Convention were enshrined earlier - in the European Disability Strategy for 2010-2020. The UN CRPD is a "mixed agreement". According to Art. 216 (2) TFEU international agreements concluded by the EU are binding for institutions as well as for the Member States. Accordingly, the Commission may bring an infringement case against a Member State not properly implementing the UN CRPD under Art. 258 TFEU. A Member State has an EU legal obligation to implement the UN CRPD insofar as its provisions are within the scope of EU competence.

Concerning the status of the UN CRPD in the EU legal order: the UN CRPD has become an integral part of EU law; in hierarchical terms, the Convention is inferior to the provisions of the Treaty on the Functioning of the European Union and the Treaty on European Union, but superior to secondary EU law.

The CRPD is the first international, legally binding document that sets minimum standards for the rights of persons with disabilities (by the way, this Convention has taken a significant step towards the doctrinal justification of the indivisibility of human rights in international human rights law [3]), and it is the first convention on human rights where the $\mathrm{EU}$ is one of the parties. This situation has certain consequences. According to Article 216 (2) of the Treaty on the Functioning of the European Union "Agreements concluded by the Union are binding upon the institutions of the Union and on its Member States" [14]. In addition, as G. Quinn and S. Doyle point out, the position of the Court of Justice of the EU should be taken into account, which considers that while international agreements concluded by the EU are inferior to the EU Treaties they nonetheless rank superior to secondary EU law. Therefore, 'post-confirmation' EU legislative proposals must be self-consciously crafted not only to fit with, but also help to advance, the goals of the UN CRPD [74, p. 70].

It should be noted that the signing of the CRPD by the European Union was seen as an extremely positive step (the European Union Acquires a Human Face) [61]. However, since the UN CRPD refers to "mixed agreements" in the sense that they engage the often overlapping legal competences of the Union and its Member States, this raises a number of complex issues, in particular what convention obligations are imposed on the EU, and which of them are imposed on the Member States, as well as what is covered by their common competence, how should the EU Structural Funds be involved in the implementation of the tasks of the Convention $[77 ; 91 ; 90]$ ?

The EU, as a CRPD party, is obliged to periodically inform the UN Committee on the Rights of Persons with Disabilities of the measures taken to implement it. In

\footnotetext{
${ }^{1}$ The UN CRPD has been signed and ratified by all Member States, and 22 of them have also signed and ratified the Optional Protocol thereto (2019).
} 
2014, the European Commission submitted its first report on the application of the Convention in the European Union. In May 2015, after the first meeting between the Committee and the EU in April in Geneva, the Committee on Civil Liberties, Justice and Home Affairs stated that shares the concerns of the UN CRPD Committee in relation to the European Union's lack of a clear strategy for implementing the UN CRPD. In this regard, he called on the EU to take certain steps, in particular [69]:

- Underlines the need to ensure that discrimination in all aspects on the grounds of disability is prohibited in the European Union, including multiple and intersectional discrimination;

- Calls on the Commission to revise its Disability Strategy 2010-2020 with a view to the full implementation of the UN Convention on the Rights of Persons with Disabilities;

- Calls on the Commission to maximize synergies between the EU Disability Strategy 2010-2020 and the provision of the UN Convention on the Elimination of all Forms of Discrimination Against Women and the UN Convention on the Rights of the Child;

- Underlines the need to include a clear gender perspective in a new European Disability Strategy;

- Strongly deplores the fact that the Council has still not adopted the 2008 proposal for a directive on implementing the principle of equal treatment between persons irrespective of religion or belief, disability, age or sexual orientation;

- Calls for the EU institutions and the Member States to give persons with disabilities an active role in decision-making processes, including through their representative organizations, in accordance with Article 4(3) of the CPRD.

Ensuring the full participation of people with disabilities in social life in each Member State and in the European Union as a whole, combating discrimination, removing barriers and combating social exclusion has become the EU's main task in protecting the rights of people with disabilities. The signing of the CRPD obliges the EU institutions to implement its provisions. This, in turn, necessitated the development and adoption of a tool for the full implementation of the provisions of the Convention. Such an instrument was "European Disability Strategy 20102020: A Renewed Commitment to a Barrier-Free Europe" [44] (hereinafter - the Strategy), which is intended to harness the combined potential of the EU Charter of Fundamental Rights, the Treaty on the Functioning of the European Union, and the UN Convention, and to make full use of Europe 2020 and its instruments. The EU is obliged to support and complement national initiatives on CRPD requirements implementation through its own strategic actions [9, p. 19].

The Strategy is based on the values enshrined in the Founding Treaties, on the experience of previous foundations of EU policy on people with disabilities, as well as on the priorities of "Europe 2020: A strategy for smart, sustainable and inclusive

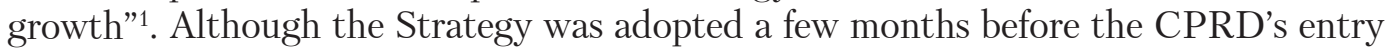

\footnotetext{
${ }^{1}$ The Strategy states that the Commission should seek to: to transform the open method of coordination on social exclusion and social protection into a platform for cooperation, peer-review and exchange of
} 
into force for the EU, its content was largely shaped by the Convention's influence. The main aim of the Strategy is to empower people with disabilities so that they can enjoy their full rights, and benefit fully from participating in society and in the European economy [44].

The European Disability Strategy is not the first comprehensive EU document which reflects the EU's disability policy. Thus, in 1996 the Commission adopted a strategy "Equality of Opportunity for People with Disabilities - A New Community Disability Strategy 1996". The latter has been politically endorsed in a Resolution of the Council of Ministers in December 1996 [1; 79]. In 2003, "Equal Opportunities for People with Disabilities: A European Action Plan" [42] was adopted for the period 2004-2010. The Union's commitment to the social model of disability was clearly reflected in the content of the Plan: "The EU's long-standing commitment towards its disabled citizens go hand in hand with a new approach to disability: from seeing people with disabilities as the passive recipients of compensation, society has come to recognize their legitimate demands for equal rights and to realize that participation relates directly to insertion"1. The plan was based on 3 pillars (antidiscrimination, mainstreaming, accessibility) and provided for three biennial phases [47; 12], preceded by Communication from the Commission to the Council, the European Parliament, the European Economic and Social Committee and the Committee of the Regions [10-12]:

- 2004-2005 - creating the conditions necessary to promote the employment of people with disabilities, while making the mainstream labor market more accessible to them across the enlarged Union;

- 2006-2007 - the priority areas are encouraging activity; providing access to quality support and care services for disabled people; fostering accessibility for all; and increasing the Union's information gathering and analytical capacity;

- 2008-2009 accessibility as a priority for active inclusion and access to rights. Accessibility enables the heterogeneous needs of men and women with disabilities to be addressed in an integrated manner.

Compared to the Action Plan, the Strategy focuses on the accessibility of goods and services in the internal market [6, p. 30-31], as well as on the systematic involvement of the potential of representative organizations of people with disabilities in the development of EU disability policy.

The Commission has identified eight main areas for action and key actions are identified for each of them, together with an indication of the main EU tasks in each of the areas, namely:

good practice, and into an instrument to foster commitment by public and private players to reduce social exclusion, and take concrete action, including through targeted support from the structural funds, notably the ESF; to design and implement programmes to promote social innovation for the most vulnerable, in particular by providing innovative education, training, and employment opportunities for deprived communities, to fight discrimination (e.g. disabled) [43].

${ }^{1}$ The Plan mentioned: «to shaping society in a fully inclusive way is therefore the overall EU objective: in this respect, the fight against discrimination and the promotion of the participation of people with disabilities into economy and society play a fundamental role» [42]. 
1) accessibility - ensuring access to goods, services, including public services and assistive devices for people with disabilities;

2) participation - to achieve full participation of persons with disabilities in society by enabling them to enjoy all the benefits of EU citizenship; removing administrative and attitudinal barriers to full and equal participation; providing quality community-based services, including access to personal assistance;

3 ) equality - eradication of discrimination on the grounds of disability in the EU;

4) employment - enable many more people with disabilities to earn their living on the open labour market;

5) education and training - promoting inclusive education and lifelong learning for pupils and students with disabilities;

6) social protection - promoting decent living conditions for people with disabilities;

7) health - foster equal access to health services and related facilities for people with disabilities;

8) external action - promotion of the rights of people with disabilities within the EU external action [44].

European Disability Strategy 2010-2020 was accompanied by two documents: the comprehensive Commission Staff Working Document SEC(2010) 1323, providing factual evidence and supporting data for the EDS, including input received from stakeholders during the consultation process; and a "list of actions" (SEC(2010) 1324), which constitutes the operational implementation plan for the first five years across the EDS' thematic priorities and its general implementation instruments.

The "list of actions" included a number of numerous measures, including the development of legislation as well as the use of other necessary policy instruments (soft law, standards and research/studies) within the EU's competence on the principle of subsidiarity ${ }^{1}$ adhering and within the timeframe set out in the Strategy [84].

Effective implementation of the Strategy depends on such general implementation tools as: raising society's awareness of disability issues and foster knowledge among people with disabilities of their rights and how to exercise them; optimizing use of EU funding instruments to ensure accessibility and nondiscrimination, as well as raising awareness on funding opportunities; supplement the collection of periodic disability-related statistics with a view to monitoring the situation of persons with disabilities.

The adoption of the European Disability Strategy for 2010-2020 was an important event in the field of persons' with disabilities rights protection. EU institutions and NGOs in general supported this document. At the same time, the European Parliament criticised the EDS for lacking a gender perspective on disability policy or a separate chapter on gender policy [46]. The European

\footnotetext{
${ }^{1}$ The Strategy states that EU actions in each of the thematic directions serve to support and supplement national disability policies.
} 
Economic and Social Committee [70] and the European Disability Forum (EDF) [84] also commented and made suggestions about EDS.

Implementing such a complex and long-term policy as the European Disability Strategy 2010-2020 required significant efforts. Many of the proposed measures of the Strategy are designed to support or complement actions at the national level. It means that the implementation of many provisions of the Strategy depends on the Member States. That is why the impact of the Strategy may not be felt immediately: it will probably require a much longer time frame before widespread noticeable improvement occurs [24, p. 98]. Therefore, the effectiveness of the Strategy's measures assessed only years after they have been applied on the ground. It was the reason why it was envisaged that the Commission's reports on progress should be prepared by the end of 2013 and 2016, including on Member States' actions and the EU report to the UN Committee on the Rights of Persons with Disabilities. However, the deadlines were not met, as indicated by the UN Committee on the Rights of Persons with Disabilities in its 2015 concluding observations and it was recommended to carry out a mid-term evaluation of the Strategy by the EU and to establish clear guidelines for including the recommendations in the submitted concluding observations with clear criteria and indicators [13]. As a result, the Commission firstly reported to the Committee on the Convention and then continued to work on the report on the Strategy, which was published in February 2017 and covered the first five years of the Strategy action.

According to the Report, by 2020, approximately 120 million Europeans in the EU will have a disability. The share of women with disabilities in the total population is higher than the share of men (29.5\% vs. $24.5 \%)$. Despite the prohibition of discrimination in employment under the Directive for equal treatment in employment and occupation, access to the labor market remains a major problem for people with disabilities. The employment rate of people with disabilities is only $48.7 \%$, which is much lower than that of people without disabilities (72.5\%). Access to inclusive, quality education remains elusive to many people with disabilities. Only about $29.5 \%$ of people with disabilities (in the age group of 30-34 years) have completed tertiary education or its equivalent, compared to $42.5 \%$ of people without disabilities. Finally, $30 \%$ of people with disabilities are close to poverty or social exclusion in the EU, compared to $21.5 \%$ of people without disabilities. The degree of disability - severe vs moderate - significantly increases the risk of poverty or social exclusion [73]. However, this risk is significantly decreases for people aged 65 and over in almost all EU Member States due to the social protection provided after retirement. Overall, the Report notes that, despite the challenges, significant progress has been made in all major areas, but to varying degrees.

The greatest progress has been made in the area of "accessibility". Progress in this area is explained by the fact that the legal basis for most acts adopted in this area is not the competence of the EU in social policy (where it has limited powers) but Articles 26 and 114 of TFEU concerning the internal market. In accordance with Part 1 of Art. 26 TFEU, the Union shall adopt measures with the aim of 
establishing or ensuring the functioning of the internal market, in accordance with the relevant provisions of the Treaties, and Art. 114 authorizes the European Parliament and the Council of the EU to take measures to approximate the laws, regulations or administrative provisions of the Member States which have as their object the establishment and functioning of the internal market [15]. That is why EU actions in this direction can be implemented not only in the form of "soft" law. Progress towards "accessibility" is underlined by the adoption of one of the most important acts - the Directive on accessibility requirements for products and services (2019) [28] (also is known as the European Accessibility Act). This act was built to complement the EU Web Accessibility Directive which became law in 2016. It is aimed at reducing the fragmentation of legislation on access to products and services as a result of different accessibility requirements in the Member States. It also reflects the obligations of the UN's Convention on the Rights of Persons with Disabilities. The laws, regulations and administrative provisions necessary to comply with this Directive have to be adopted and published by the Member States by 28 June 2022. In 2025, the requirements of the European accessibility act must have already been implemented.

The Directive on accessibility requirements for products and services also imposes obligations on manufacturers, representatives, importers and distributors and should cover all economic operators, both public and private. It provides only functional requirements, i.e. it identifies aspects of the product / service that should be available. The Directive does not specify how it should be achieved from a technical point of view, which allows for further improvements and provides more flexibility in implementation [28]. The European Disability Forum welcomed the mentioned Directive. However, it pointed out a number of shortcomings, in particular the limited scope of its action (the list of goods and services is very limited and focused mainly on digital goods and services and does not provide access to medical services, education, transport, housing, etc.) [38].

As for the general tools for implementing the Strategy, the report states that they "have been used effectively and will be used in the coming years". However, the Report remains rather vague on existing gaps in the Strategy and on the EU's full compliance with its obligations under the Convention [73]. There is also no vision for actions after 2020 (the Report mentions their "reflection in the formation of future EU policy on people with disabilities").

It is worth noting that, although many stakeholders called for a revision of the Strategy, the Commission concluded that "the objectives of the ten-year strategy remain fully relevant" for the remainder period.

In 2020, the European Disability Strategy expires and the European Commission needs to both summarize and begin preparations for the development of a new disability policy framework. As the Strategy is in fact an instrument for the EU to implement its obligations under the Convention on the Rights of Persons with Disabilities, the UN recommendations will serve as guiding principles and, to some extent, they will set priorities for the new Disability Action Plan. 
Conclusions. Language largely shapes our awareness, as well as the way we perceive other people. The choice of terms used to describe a particular group of people and the way they are described could have a direct impact on how they feel in a particular state or integration association. The terms that define persons with disabilities in the national legislation of European countries change with the change of society's attitude to such category of persons, as well as the terminology used in relation to persons with disabilities in international legal acts. Modern approaches to the terminological definition of persons with disabilities are reflected in the UN Convention on the Rights of Persons with Disabilities.

Persons with disabilities civil society organizations have played (in the second half of the twentieth century) and (at the beginning of the XXI century) continue to play a crucial role in disability policy-making. The development of European political-legal discourses in this period reflects the radical changes in public legal awareness of such a social phenomenon as disability. Whereas initially the social policy of the EU and the Member States was focused on the care and rehabilitation of people with disabilities and at compensating for the alleged limitations of individual people with disabilities, today such policy concerns human rights, citizenship, full participation of people with disabilities in society, barriers elimination, etc. Cooperation between EU institutions, national governments and civil society organizations improves and strengthens the European disability strategy.

In the modern European Union, disability policy (which was paid extremely little attention in the framework of traditional social policy in the late twentieth century) became one of the priorities of legal regulation. Today, this area of social policy includes not only social protection and integration in the labor market, but also takes care of the problem of ensuring equal rights and non-discrimination.

The policy of Europeanization of legal regulation in the field of disability proves the important role of the supranational level of government in ensuring the rights of this category of persons. Today, in the field of legal regulation of persons' with disabilities rights, there are both bottom-up and top-down processes. At the same time, it is still at the level of the Member States the most important decisions in the field of disability policy are adopted and implemented. However, the European Union has an important role to play in modernizing this policy. Progress in disability regulation requires maximum synergies and complementarities between supranational and national levels of government.

\section{References}

1. A New European Community Disability Strategy: Communication of the Commission on Equality of Opportunity for People with Disabilities. (1996). URL: https://ec.europa.eu/employment_ social/soc-prot/disable/com406/index_en.htm.

2. Anastasiou, D., Kauffman, J.M. (2013). The Social Model of Disability: Dichotomy between Impairment and Disability. Journal of Medicine and Philosophy 38(4): 441-59. doi: https://doi. org/10.1093/jmp/jht026.

3. Beco, G. de (2018). The indivisibility of Human Rights and the Convention on the Rights of Persons with Disabilities. International and Comparative Law Quarterly, 1, 141-160. doi: https://doi. org/10.1017/s0020589318000386. 
4. Bъrca Groinne de (2011 ). The Road Not Taken: The EU as a Global Human Rights Actor. American Journal of International Law, vol. 105, issue 4, 649-693.

5. Burridge, K. (2006). Taboo, euphemism, and political corectness. In Encyclopedia of language and linguistics, ed. Keith Brown, Boston: Elsevier Ltd, 455-462.

6. Charitakis, S. (2013). An introduction to the disability strategy 2010-2020, with a focus on accessibility, 28-35. URL: http://www.nuigalway.ie/dream/downloads/an_introduction_to_the_ disability_strategy_20102020_with_a_focus_on_accessibility.pdf.

7. Charter of Fundamental Rights of the European Union (2000/C 364/01). Official Journal of the European Communities C 364/1.

8. Clasificaciyn Internacional del Funcionamiento, de la Discapacidad y de la Salud. (2001). URL: https://www.imserso.es/InterPresent2/groups/imserso/documents/binario/435cif.pdf.

9. Clifford, J. (2011). The UN Disability Convention and Its Impacton European Equality Law. The Equal Rights Review, vol. 6, 11-25. URL: https://www.equalrightstrust.org/ertdocumentbank/ ERR06_jarlath_article.pdf.

10. Communication from the Commission to the Council, the European Parliament, the European Economic and Social Committee and the Committee of the Regions - Equal opportunities for people with disabilities: A European Action Plan. COM/2003/0650. URL: https://eur-lex.europa.eu/ legal-content/en/TXT/?uri=CELEX:52003DC0650.

11. Communication from the Commission to the Council, the European Parliament, the European Economic and Social committee and the Committee of the Regions - Situation of disabled people in the enlarged European Union: the European Action Plan 2006-2007. COM/2005/0604. URL: https://eur-lex.europa.eu/legal-content/EN/TXT/?uri=CELEX:52005DC0604.

12. Communication from the Commission to the Council, the European Parliament, the European Economic and Social Committee and the Committee of the Regions - Situation of disabled people in the European Union: the European Action Plan 2008-2009. \{SEC(2007)1548\}. COM/2007/0738. URL: https://eur-lex.europa.eu/legal-content/en/TXT/?uri=CELEX:52007DC0738.

13. Concluding observations on the initial report of the European Union: Committee on the Rights of Persons with Disabilities: draft / prepared by the Committee. 2 October 2015. URL: https:// www.eurochild.org/fileadmin/public/05_Library/Thematic_priorities/01_Childrens_Rights/Other/ CRPD_C_EU_CO_1_21617_E.pdf.

14. Consolidated Texts of the EU Treaties as Amended by the Treaty of Lisbon. URL: https://assets. publishing.service.gov.uk/government/uploads/system/uploads/attachment_data/file/228848/7310. pdf.

15. Consolidated versions of the Treaty on European Union and the Treaty on the functioning of the European Union. URL: https://op.europa.eu/en/publication-detail/-/publication/3c32722f0136-4d8f-a03e-bfaf70d16349.

16. Council Decision of 26 November 2009 concerning the conclusion, by the European Community, of the United Nations Convention on the Rights of Persons with Disabilities. OJ L 23, 27.1.2010, 35-36. URL: https://eur-lex.europa.eu/legal-content/EN/TXT/?uri=CELEX\%3A32010D0048.

17. Council Directive 2000/78/EC of 27 November 2000 establishing a general framework for equal treatment in employment and occupation. Official Journal L 303. 02/12/2000, 0016-0022.

18. Council Recommendation 86/379/EEC of 24 July 1986 on the employment of disabled people in the Community: Official Journal L 225.12/08/1986, 0043-0047.

19. Council Resolution of 15 July 2003 on promoting the employment and social integration of people with disabilities. URL: https://op.europa.eu/en/publication-detail/-/publication/e571a505ddc3-496b-916e-aae7e1deb6f3/language-en.

20. Council Resolution of 27 June 1974 establishing the initial Community action programme for the vocational rehabilitation of handicapped persons. Official Journal C 080.09/07/1974, 0030-0032.

21. Council Resolution of the representatives of the Governments of the Member States of the European Communities meeting within the Council of 21 December 1981 on the social integration of handicapped people. Official Journal C 347. 31/12/1981, 0001. 
22. Dąbrowska, (1993). Eufemizmy wspyłczesnego języka polskiego. Wrocław: Wydawnictwo Uniwersytetu Wrocławskiego.

23. Dahl, V.I. (2006). Explanatory Dictionary of the Living Great Russian Language: Dictionary in 4 volumes. Moscow: RIPOL classic. Vol. 2 [in Russian].

24. David, L. (2013). Hosking Staying the course: the European Disability Strategy 2010-2020. European yearbook of disability law, vol. 4, 73-98.

25. Declaration on the Rights of Disabled Persons. Proclaimed by General Assembly resolution 3447 (XXX) of 9 December 1975. URL: https://www.ohchr.org/EN/ProfessionalInterest/Pages/ RightsOfDisabledPersons.aspx.

26. Declaration on the Rights of Mentally Retarded Persons. Proclaimed by General Assembly resolution 2856 (XXVI) of 20 December 1971. URL: https://www.ohchr.org/EN/ProfessionalInterest/Pages/RightsOfMentallyRetardedPersons.aspx.

27. Dekret o obowiązku szkolnym (8 February 1919). (1919). URL: http://prawo.sejm.gov.pl/ isap.nsf/download.xsp/WDU19190140147/O/D19190147.pdf.

28. Directive (EU) 2019/882 of the European Parliament and of the Council of 17 April 2019 on the accessibility requirements for products and services. Official Journal of the European Union L 151. 7.6.2019, 70-115.

29. Directive 2001/83/EC of the European Parliament and of the Council of 6 November 2001 on the Community code relating to medicinal products for human use. Official Journal L 311. 28.11.2001, 67.

30. Directive 2001/85/EC of the European Parliament and of the Council of 20 November 2001 relating to special provisions for vehicles used for the carriage of passengers comprising more than eight seats in addition to the driver's seat, and amending Directives 70/156/EEC and 97/27/EC. URL: https://eur-lex.europa.eu/legal-content/EN/TXT/?uri=CELEX\%3A32001L0085.

31. Directive 2002/21/EC of the European Parliament and of the Council of 7 March 2002 on a common regulatory framework for electronic communications networks and services (Framework Directive). Official Journal L 108. 24.4.2002, 33-50.

32. Directive 2004/17/EC of the European Parliament and of the Council of 31 March 2004 coordinating the procurement procedures of entities operating in the water, energy, transport and postal services sectors. Official Journal L 134. 30.4.2004, 1-113.

33. Directive 2004/18/EC of the European Parliament and of the Council of 31 March 2004 on the coordination of procedures for the award of public works contracts, public supply contracts and public service contracts. Official Journal L 134. 30.4.2004, 114-24. ablism.

34. Disability and Disabilism. URL: https://www.coe.int/ru/web/compass/disability-and-dis-

35. Dominick, M.F. (1990). Toward a Community Bill of Rights: The European Community Charter of Fundamental Social Rights. Fordham International Law Journal, vol. 14, issue 3, art. 4, 639-668.

36. Draft Treaty embodying the Statute of the European Community. Information and official documents of the Constitutional Committee. October 1952-April 1953. Published by the Secretariat of the Constitutional Committee. URL: http://aei.pitt.edu/991/1/political_union_draft_treaty_1. pdf.

37. Dubisz, S. (2013). Uniwersalny słownik języka polskiego. Warszawa: Wydawnictwo Naukowe PWN, vol. 1-4.

38. EDF analysis of the European Accessibility Act. URL: http://www.edf-feph.org/sites/ default/files/edf_analysis_of_the_european_accessibility_act_-_june_2019_1.doc\#overlaycontext=newsroom/news/our-analysis-european-accessibility-act.

39. EMP-HELIOS 1 - Second Community action programme (EEC) for disabled people (HELIOS), 1988-1991. URL: https://cordis.europa.eu/programme/id/EMP-HELIOS-1.

40. EMP-HELIOS 2 - Third Community action programme (EEC) for disabled people (HELIOS II), 1993-1996. URL: https://cordis.europa.eu/programme/id/EMP-HELIOS-2. 
41. Ending forced sterilisation of women and girls with disabilities. (2017). URL: http://www. edf-feph.org/sites/default/files/edf_forced-sterilisation_8-accessible_6.pdf.

42. Equal opportunities for people with disabilities: A European Action Plan. Communication from the Commission to the Council, the Europaean Parliament, the Euroean Economic and Social Committee and the Committee of the Regions. Brussels, 30.10.2003. URL: https://ailevecalisma.gov. tr/uploads/eyhgm/uploads/pages/2003europeanactionplani-5b3a32280becc.pdf.

43. Europe 2020: A strategy for smart, sustainable and inclusive growth. Communication from Commission. Brussels, 3.3.2010. COM(2010) 2020. URL: https://ec.europa.eu/eu2020/pdf/ COMPLET\%20EN\%20BARROSO\%20\%20\%20007\%20-\%20Europe\%202020\%20-\%20EN\%20 version.pdf.

44. European Disability Strategy 2010-2020: A Renewed Commitment to a Barrier-Free Europe: Communication COM (2010) 636 from the Commission to the European Parliament, the Council, the European Economic and Social Committee and the Committee of Regions. Brussels, 15.11.2010. COM(2010) 636 final. URL: https://eur-lex.europa.eu/LexUriServ/LexUriServ.do?uri=COM\%3A20 10\%3A0636\%3AFIN\%3AEN\%3APDF.

45. Bercusson, B. (Ed.). (2002). European labour law and the EU Charter of Fundamental Rights. Brussels: ETUI.

46. European Parliament resolution of 25 October 2011 on mobility and inclusion of people with disabilities and the European Disability Strategy 2010-2020 (2010/2272(INI)). URL: http://www. europarl.europa.eu/sides/getDoc.do?type $=$ TA\&language $=$ EN\&reference $=$ P7-TA-2011-453.

47. Explanatory Memorandum to COM(2007)738 - Situation of disabled people in the EU: the European Action Plan 2008-2009. URL: https://www.eumonitor.eu/9353000/1/j4nvhdfdk3hydzq j9vvik7m1c3gyxp/vikqhm1qj5yq.

48. Forced sterilization of young women with disabilities must end, UN rights expert says. URL: https://www.ohchr.org/EN/NewsEvents/Pages/DisplayNews.aspx?NewsID=22289\&LangID=E.

49. Friedlander, S. (1998). Nazi Germany and the Jews: The Years of Persecution. New York, NY: Harper Collins.

50. Grodin, M.A., Miller, E.L., Kelly, J.I. (2018). The Nazi Physicians as Leaders in Eugenics and «Euthanasia»: Lessons for Today. Am J Public Healthv, 108(1). doi: 10.2105/AJPH.2017.304120.

51. Grue, L. (2010). Eugenics and euthanasia - then and now. Scandinavian Journal of Disability Research. Vol. 12, issue 1, 33-45. doi: 10.1080/15017410903076776.

52. Guide to the Amsterdam Treaty. European Disability Forum. (1998). URL: https://www. independentliving.org/docs3/edf98.html.

53. Héctor Álvarez García (2017). La tutela constitucional de las personas con discapacidad. Revista de Derecho Politico, 100, 1027-1055. doi: 10.5944/rdp.100.2017.20725.

54. Henckes. N. (2012). Entre maladie et handicap: repenser la critique psychiatrique de la loi du 30 juin 1975 d'orientation en faveur des personnes handicapées. ALTER, European Journal of Disability Research 6, 242-254.

55. Human Rights and Disability. (2002). The current use and future potential of United Nations human rights instruments in the context of disability. New York and Geneva, URL: https://www. ohchr.org/Documents/Publications/HRDisabilityen.pdf.

56. Informations et Documents Officiels de la Commission Constitutionnelle, Assemdee ad hoc Chargee D'Elaborer un Project de Traite Instituant une Communaute Politique Europeenne (March 1955), Document 15, Title III B.

57. International Convention of the Rights of Persons with Disabilities and its Optional Protocol, U.N. GAOR, 61st Sess., Item 67(b), U.N. Doc. A/61/611 (Dec. 6, 2006).

58. Kevles, D. (1985). In the Name of Eugenics. Berkeley and Los Angeles, CA: University of California Press.

59. Kostyuk, V. (2016). Problems of harmonization of the legislation of Ukraine on the rights of persons with disabilities with the relevant standards of the European Union. Law of Ukraine, 8, 47-54 [in Ukrainian]. 
60. Utchenko, S.L. (Ed.). (1962). Law of the Twelve Tables. Readers on the history of Ancient Rome. Moscow: Sotsekgiz, 62-72 [in Russian].

61. Lawson, A. (2009). The UN Convention on the Rights of Persons with Disabilities and European disability law: A catalyst for cohesion? The UN Convention on the Rights of Persons with Disabilities: European and Scandinavian Perspectives. Vol. 100, 81-109. Series: International Studies in Human Rights. doi: https://doi.org/10.1163/ej.9789004169715.i-320.30.

62. Lifton, RJ. (1986).The Nazi Doctors: Medical Killing and the Psychology of Genocide. New York, NY: Basic Books.

63. McSherry, B. (2017). Regulating seclusion and restraint in health care settings: The promise of the Convention on the Rights of Persons with Disabilities. International Journal of Law and Psychiatry. Vol. 53, 39-44. doi: https://doi.org/10.1016/j.ijlp.2017.05.006.

64. Melnik, V. (2017). Rights of persons with disabilities under EU law: issues of legal regulation. Public laze, 3 (27), 160-166 [in Ukrainian].

65. Melnik, V. (2018). Persons with disabilities social protection: principles of legal regulation of individual EU member states. Entrepreneurship, economy and law, 7, 133-138 [in Ukrainian].

66. Munoz, Luis A. Galvez (2017). El régimen de la participaciyn electoral de las personas con discapacidad en los cuarenta acos de democracia. Revista de Derecho Político, 100, 1057-1096. doi: https://doi.org/10.5944/rdp.100.2017.20726.

67. Nowak-Michalska, J. (2020). The Dynamics of Euphemisation in Legal Language: An Analysis of Legal Terms Referring to People with Disabilities Used in Poland and Spain. International Journal for the Semiotics of Law - Revue internationale de Sümiotique juridique. Vol. 33, issue 1. DOI: 10.1007/ s11196-020-09699-5. URL: https://link.springer.com/article/10.1007/s11196-020-09699-5.

68. Oorschot, van W., Hvinden, B. (2000). Introduction: Towards Convergence? Disability Policies in Europe. European Journal of Social Security, 2 (4), 293-302.

69. Opinion of the Committee on Civil Liberties, Justice and Home Affairs (25.5.2016) for the Committee on Employment and Social Affairs on the implementation of the UN Convention on the Rights of Persons with Disabilities with special regard to the concluding observations of the UN CRPD Committee (2015/2258(INI)). URL: https://www.europarl.europa.eu/doceo/ document/A-8-2016-0203_EN.html\#_part2_def2.

70. Opinion of the European Economic and Social Committee on the "Communication from the Commission to the European Parliament, the Council, the European Economic and Social Committee and the Committee of the Regions - European Disability Strategy 2010-2020: A renewed commitment to a barrier-free Europe”. COM(2010) 636 final. URL: https://eur-lex.europa.eu/legal-content/EN/ ALL/?uri=CELEX:52011AE1382.

71. Priestley, M. (2005). We're all Europeans now! The social model of disability and European social policy. Barnes C., Mercer G. (Eds.) The Social Model of Disability: Europe and the Majority World. Leeds: The Disability Press, 17-31.

72. Priestley, M. (2007). In search of European disability policy: Betweennational and global. ALTER, Revue européenne de recherchesur le handicap, 1, 61-74.

73. Progress Report on the implementation of the European Disability Strategy (2010-2020): Commission Staff Working Document. URL: https://ec.europa.eu/social/BlobServlet?docId=16995 \&langId $=$ en.

74. Quinn, G., Doyle, S. (2012). Taking the UN Convention on the Rights of Persons with Disabilities Seriously: The Past and Future of the EU Structural Funds as a Tool to Achieve Community Living. The Equal Rights Review, Vol. 9, 69-94.

75. Regulation (EC) No 1107/2006 of the European Parliament and of the Council of 5 July 2006 concerning the rights of disabled persons and persons with reduced mobility when travelling by air (Text with EEA relevance). Official Journal L 204. 26.7.2006, 1-9.

76. Regulation (EC) No 261/2004 of the European Parliament and of the Council of 11 February 2004 establishing common rules on compensation and assistance to passengers in the event of denied boarding and of cancellation or long delay of flights, and repealing Regulation (EEC) No 295/91 (Text with EEA relevance) - Commission Statement. Official Journal L 46. 17.2.2004, 1-8. 
77. Reiss. J.W. (2014). Innovative Governance in a Federal Europe: Implementing the Convention on the Rights of Persons with Disabilities. European Law Journal, vol. 20, issue 1, 107-125. doi: https://doi.org/10.1111/eulj.12050.

78. Resolution adopted by the General Assembly. [on the report of the Third Committee (A/48/627)] 48/96. Standard Rules on the Equalization of Opportunities for Persons with Disabilities. URL: $\quad$ https://www.un.org/development/desa/disabilities/standard-rules-on-the-equalization-ofopportunities-for-persons-with-disabilities.html.

79. Resolution of the Council and of the Representatives of the Governments of the Member States meeting within the Council of 20 December 1996 on equality of opportunity for people with disabilities. URL: https://ec.europa.eu/employment_social/soc-prot/disable/com406/res en.htm.

80. Riku-Heikki Virtanen (2018). Towards a Permanent Consultation Mechanism for Persons with Disabilities. A Study from the Perspective of the Un Convention on the Rights of Persons with Disabilities. Baltic Journal of Law E F Politics. 11:1 (2018): 158-186. doi: https://doi.org/10.2478/ bjlp-2018-0007.

81. Single European Act. (1987). Official Journal of the European Communities. No L 169/1.

82. Sytnyk, A. (2014). Argumentative Euphemisms, Political Correctness and Relevance: Thèse présentée a la Faculté des lettres et sciences humaines Institut des sciences du langage et de la communication Université de Neuchâtel Pour l'obtention du grade de Docteur us Lettres. URL: https:// doc.rero.ch/record/232366/files/00002415.pdf.

83. The Community Charter of Fundamental Social Rights for Workers. (1989). URL: http://aei. pitt.edu/4629/1/4629.pdf.

84. The European Disability Strategy 2010-2020: Briefing Implementation in action. July 2017. URL: http://www.europarl.europa.eu/RegData/etudes/BRIE/2017/603252/EPRS_ BRI(2017)603252_EN.pdf.

85. The Optional Protocol to the Convention on the Rights of Persons with Disabilities. URL: https://treaties.un.org/doc/Publication/CTC/Ch-15-a.pdf.

86. Varney, E. (2017). Redefining contractual capacity? the UN Convention on the Rights of Persons with Disabilities and the incapacity defence in English contract law. Legal Studies, 3, 493519. doi: https://doi.org/10.1111/lest.12166.

87. Vienna Declaration and Programme of Action, Adopted by the World Conference on Human Rights in Vienna on 25 June 1993. URL: https://www.ohchr.org/en/professionalinterest/pages/ vienna.aspx.

88. Waddington, L. (1997). The European Community and disability discrimination:Time to address the deficit of powers? Disability and Society, 12 (3), 465-479.

89. Waddington, L. (2006). From Rome to Nice in a Wheelchair the Development of a European Disability Policy. Europa Law Publishing.

90. Waddington, L. (2009). Breaking New Ground: The Implications Of Ratification Of The UN Convention On The Rights Of Persons With Disabilities For The European Community. The UN Convention on the Rights of Persons with Disabilities: European and Scandinavian Perspectives. Vol. 100, 111-140. Series: International Studies in Human Rights. doi: https://doi.org/10.1163/ ej.9789004169715.i-320.37.

91. Waddington, L. (2011). The European Union and the United Nations Convention on the Rights of Persons with Disabilities: A Story of Exclusive and Shared Competences. Maastricht Journal of European and Comparative Law. Vol. 18, issue 4, 431-453. https://doi. org/10.1177/1023263X1101800404.

Maйданик C. B., аспирант кафедры права Европейского Союза, Национальный юридический университет имени Ярослава Мудрого, Украина, г. Харьков.

e-mail: s.v.maydanik@nlu.edu.ua ; ORCID 0000-0001-7837-5265 
Политика Европейского Союза в сфере инвалидности: наднациональный уровень правового регулирования

В современном Европейском Союзе политика в сфере инвалидности, которой в конце XX в. уделялось очень мало внимания в рамках традиционной социальной политики, превратилась в один из приоритетов правового регулирования. Сегодня это направление социальной политики включает не только социальную защиту и интегращию на рынке труда, но и занимается проблемой обеспечения равенства прав и недискриминации. В контексте этой эволючии в статье исследуются такие вопросы: какова правовая природа Европейского Союза? Какое влияние на политику инвалидности имеет появление наднащионального уровня правового регулирования? Как соотносится международно-правовой и общеевропейский уровень правового регулирования в сфере инвалидности? Как менялась терминология в нормативно-правовых актах международно-правового, регионального и национального уровней? Как эволюиионировала и под влиянием каких факторов политика ЕС по инвалидности? В статье представлены результаты системного анализа нормативных документов ЕС по политике в сфере инвалидности, охватьвающих период с 1951 по 2020 год.

Ключевые слова: лица с инвалидностью; права лиц с инвалидностью; равные права; социальная модель; Европейский Союз; социальная политика; компетенция; Конвенция о правах инвалидов.

Рекомендоване цитування: Maidanik S. V. European union disability policy: supranational level of legal regulation. Проблеми законності. 2020. Вип. 150. С. 332-353. doi: https://doi. org/10.21564/2414-990x.150.209404.

Suggested Citation: Maidanik, S.V. (2020). European union disability policy: supranational level of legal regulation. Problemy zakonnosti - Problems of Legality, issue 150, 332-353. doi: https://doi. org/10.21564/2414-990x.150.209404.

Надійшла до редколегії 05.08.2020 р. 